\title{
Endometrial Transitional Cell Carcinoma
}

National Cancer Institute

\section{Source}

National Cancer Institute. Endometrial Transitional Cell Carcinoma. NCI Thesaurus. Code C40154.

A rare primary carcinoma of the endometrium characterized by the presence of malignant epithelial cells resembling urothelial transitional cells. The malignant transitional cells constitute at least $90 \%$ of the tumor cells. 